\title{
Kary pieniężne za nielegalne umieszczanie tablic reklamowych lub urządzeń reklamowych
}

\section{Penalty payments for placement of advertising boards and structures}

Streszczenie. W opracowaniu przedstawiono istotę, przesłanki zastosowania oraz zasady wymiaru kar pieniężnych za umieszczanie w przestrzeni publicznej tablic reklamowych lub urządzeń reklamowych z naruszeniem zasad i warunków ich sytuowania określonych w uchwale rady gminy będącej aktem prawa miejscowego. Podstawowe elementy konstrukcyjne kar pieniężnych określono w ustawie o planowaniu i zagospodarowaniu przestrzennym. Wysokość kary pieniężnej określa, w drodze decyzji, wójt (burmistrz, prezydent miasta). Mechanizm ustalania wysokości kary pieniężnej ustalono w ustawie i uwzględnia on powierzchnię tablicy lub urządzenia przeznaczonego do ekspozycji reklamy oraz wielokrotność stawki opłaty reklamowej określonej przez radę gminy dla danego obszaru albo maksymalnej stawki tej opłaty przyjętej w ustawie. Wpływy z kar pieniężnych są źródłem dochodów własnych gminy i można je zaliczyć do tzw. niepodatkowych należności budżetowych. 
Słowa kluczowe: tablice i urządzenia reklamowe; kształtowanie krajobrazu; kary pieniężne; budżet gminy.

\begin{abstract}
The paper presents the essence, premises of application and sentencing guidelines regarding penalty payments for placement of advertising boards or structures in the public space in violation of regulations and conditions for placement thereof stipulated in the Commune Council resolution (ordinance). Structural elements constituting penalty payments are specified in the Planning and Development Act. The amount of penalty is determined by a decision taken by commune administrator (town mayor, city mayor). The ordinance specifies criteria for establishing the amount of penalty payments, taking into consideration the size of the advertising board or structure and the multiple of applicable advertising fees specified by the Commune Council for a given area or maximum fee recognized in the ordinance. Proceeds from penalty payments constitute a source of municipality's own revenue, and are included among the so-called non-tax budget receivables.
\end{abstract}

Keywords: advertising boards and structures; landscaping; penalty payments; municipal budget.

\title{
1. Wprowadzenie
}

Celem opracowania jest analiza i ocena obowiązującego ustawodawstwa w zakresie wymiaru oraz egzekwowania kar pieniężnych za niezgodne z prawem umieszczanie w przestrzeni publicznej tablic reklamowych oraz urządzeń reklamowych. Należy podkreślić, że nie są to jedyne sankcje, które mogą być stosowane w związku z ochroną krajobrazu rozumianego jako postrzegana przez ludzi przestrzeń, zawierająca elementy przyrodnicze lub wytwory cywilizacji, ukształtowana w wyniku działania czynników naturalnych lub działalności człowieka ${ }^{1}$. W połowie 2015 r. podjęto działania legislacyjne zmierzające do „wzmocnienia” narzędzi ochrony krajobrazu², którymi są m.in. publicznoprawna opłata reklamowa stano-

1 Por. art. 2 pkt 16e ustawy z dnia 27 marca 2003 r. o planowaniu i zagospodarowaniu przestrzennym (tekst jedn. Dz.U. z 2017 r., poz. 1073), dalej: u.p.g.p.

2 Ich efektem było uchwalenie ustawy z dnia 24 kwietnia 2015 r. o zmianie niektórych ustaw w związku ze wzmocnieniem narzędzi ochrony krajobrazu (Dz.U. z 2015 r., poz. 774). 
wiąca źródło dochodów własnych gmin, a także kary (ograniczenia wolności, grzywny oraz kary pieniężne) za nielegalne umieszczanie w przestrzeni publicznej tablic reklamowych oraz urządzeń reklamowych.

Sankcje w postaci kary ograniczenia wolności lub grzywny mogą być stosowane na podstawie ustawy z dnia 20 maja 1971 r. Kodeks wykroczeń $^{3}$ za umieszczenie reklamy z naruszeniem warunków jej sytuowania albo o gabarytach większych niż dopuszczalne lub wykonanej z wyrobów innych niż dopuszczalne. Z przepisów ustawy z dnia 23 lipca 2003 r. o ochronie zabytków i opiece nad zabytkami ${ }^{4}$ wynika natomiast możliwość stosowania takich samych kar za umieszczanie bez pozwolenia na zabytku wpisanym do rejestru urządzeń technicznych, tablic reklamowych lub urządzeń reklamowych.

Kary pieniężne za nielegalne umieszczanie w przestrzeni publicznej tablic reklamowych oraz urządzeń reklamowych przewidują natomiast postanowienia art. 40 ustawy z dnia 21 marca 1985 r. o drogach publicznych $^{5}$. Są one wymierzane w decyzji administracyjnej wydawanej przez zarządcę drogi w wysokości 10-krotności opłaty ustalanej za zajęcie pasa drogowego w celu umieszczenia reklamy ${ }^{6}$. W piśmiennictwie wskazuje się, że ww. kara pieniężna - obok funkcji represyjnej i prewencyjnej realizuje również, jako wiodącą, funkcję kompensacyjną, stanowiąc ekwiwalent za szkodę wyrządzoną niewykonaniem nałożonego przez prawo obowiązku wyrażającego się w nakazie uzyskania zezwolenia na zajęcie pasa drogowego oraz uiszczenia należnej opłaty w wysokości określonej w tym zezwoleniu ${ }^{7}$. Jest ona szczególną formą odszkodowania za straty w dobrach społecznie chronionych, jakimi są obszar, przestrzeń

\footnotetext{
Tekst jedn. Dz.U. z 2015 r., poz. 1094 ze zm.

Tekst jedn. Dz.U. z 2014 r., poz. 1446 ze zm.

Tekst jedn. Dz.U. z 2016 r., poz. 1440 ze zm.

Opłata jest ustalana jako iloczyn liczby metrów kwadratowych powierzchni pasa drogowego zajętej przez rzut poziomy powierzchni reklamy, liczby dni zajmowania pasa drogowego i stawki opłaty za zajęcie $1 \mathrm{~m}^{2}$ pasa drogowego.

$7 \quad$ W. Kręcisz, Kary i opłaty za zajęcie pasa drogowego na cele niezwiq̨zane z użytkowaniem dróg w orzecznictwie sq̨dów administracyjnych, „Zeszyty Naukowe Sądownictwa Administracyjnego” 2014, nr 2, s. 29.
} 
pasa drogowego oraz obiekty infrastruktury drogowej ${ }^{8}$. W zależności od kategorii drogi publicznej wpływy z tytułu tych kar pieniężnych są przekazywane odpowiednio do budżetów jednostek samorządu terytorialnego lub na wyodrębniony rachunek bankowy Generalnej Dyrekcji Dróg Krajowych i Autostrad.

Od 11 września 2015 r. obowiązują przepisy art. 37a oraz 37d u.p.g.p. stanowiące podstawę nakładania kary pieniężnej na podmiot umieszczający tablicę reklamową lub urządzenie reklamowe niezgodnie z przepisami uchwały rady gminy ustalającej zasady i warunki sytuowania tablic reklamowych i urządzeń reklamowych. W opracowaniu przedstawiono zasady wymiaru tych kar pieniężnych, podmioty zobowiązane do ich zapłaty oraz przeznaczenie wpływów pochodzących z tych kar. Wpływy z opłat reklamowych oraz z kar pieniężnych za nielegalne umieszczanie tablic i urządzeń reklamowych są źródłami dochodów gmin. Prawna konstrukcja tej kary, jej ścisłe relacje z opłatą reklamową oraz sposób wymiaru i poboru są głównymi argumentami uzasadniającymi potrzebę dokonania analizy i oceny materiału normatywnego, dorobku judykatury oraz regionalnych izb obrachunkowych sprawujących nadzór i kontrolę gospodarki finansowej gmin, w tym w odniesieniu do uchwał rad gmin określających ww. kary pieniężne. Przeprowadzane analizy umożliwią również identyfikację funkcji realizowanych przez kary pieniężne, w tym funkcji represyjnej i dochodowej. W związku z tym podstawową metodą badawczą jest metoda dogmatycznoprawna uzupełniona metodami analityczną i empiryczną.

\section{Ustawowe definicje pojęć „tablica reklamowa” oraz „urządzenie reklamowe”}

Legalnym definicjom pojęć „tablica reklamowa” oraz „urządzenie reklamowe” sformułowanym w art. 2 pkt 16b oraz pkt 16c u.p.g.p. ustawodawca nadał charakter systemowy i uniwersalny. Do tych definicji stosowane

8 K. Sobieralski, Charakter prawny kary za zajęcie pasa drogowego, „Nowe Zeszyty Samorządowe” 2015, nr 2, s. 19. 
są bowiem odesłania z odrębnych ustaw, np. z art. 1a ust. 1 pkt 3a ustawy z dnia 12 stycznia 1991 r. o podatkach i opłatach lokalnych ${ }^{9}$ lub z art. 4 pkt 23 ustawy o drogach publicznych. W przepisach innych ustaw stosowane są te pojęcia, ale bez ich precyzyjnego uszczegółowienia oraz bez wyraźnego odesłania do postanowień ustawy o planowaniu i zagospodarowaniu przestrzennym, np.:

- $\quad$ w art. 15 oraz art. 45 ustawy z dnia 16 kwietnia 2004 r. o ochronie przyrody $^{10}$ (przepisy wprowadzają zakazy umieszczania w parkach narodowych i rezerwatach przyrody tablic, napisów, ogłoszeń reklamowych i innych znaków niezwiązanych z ochroną przyrody, albo możliwość wprowadzenia zakazu umieszczania tablic reklamowych w stosunku do pomnika przyrody, stanowiska dokumentacyjnego, użytku ekologicznego lub zespołu przyrodniczo-krajobrazowego),

- $\quad$ art. $13^{1}$ ustawy z dnia 26 października 1982 r. o wychowaniu w trzeźwości i przeciwdziałaniu alkoholizmowi ${ }^{11}$ (wprowadza zakaz reklamy i promocji piwa na słupach i tablicach reklamowych i innych stałych i ruchomych powierzchniach wykorzystywanych do reklamy, chyba że 20\% powierzchni reklamy zajmować będą widoczne i czytelne napisy informujące o szkodliwości spożycia alkoholu lub o zakazie sprzedaży alkoholu małoletnim),

- $\quad$ art. 41 ustawy z dnia 28 lipca 2005 r. o lecznictwie uzdrowiskowym, uzdrowiskach i obszarach ochrony uzdrowiskowej oraz o gminach uzdrowiskowych $^{12}$ (dotyczy nakazu zamieszczania w statucie uzdrowiska lub w statucie obszaru ochrony uzdrowiskowej postanowień o formach i miejscach lokalizacji tablic i urządzeń reklamowych).

Jeżeli w przepisach odrębnych ustaw nie sformułowano legalnych definicji pojęć „tablica reklamowa” lub „urządzenie reklamowe” i jednocześnie nie odesłano w tym zakresie wprost do postanowień ustawy o planowaniu i zagospodarowaniu przestrzennym, to uzasadnione jest odwołanie się do definicji, którym ustawodawca nadał charakter syste-

$9 \quad$ Tekst jedn. Dz.U. z 2016 r., poz. 716 ze zm., dalej: u.p.o.l.

10 Tekst jedn. Dz.U. z 2016 r., poz. 2134 ze zm.

11 Tekst jedn. Dz.U. z 2016 r., poz. 487 ze zm.

12 Tekst jedn. Dz.U. z 2016 r., poz. 879 ze zm. 
mowy i uniwersalny, a więc do definicji zawartych w ustawie o planowaniu i zagospodarowaniu przestrzennym. Zgodnie z art. 2 pkt 16b u.p.g.p. „tablicą reklamową” jest przedmiot materialny przeznaczony lub służący ekspozycji reklamy wraz z jego elementami konstrukcyjnymi i zamocowaniami, o płaskiej powierzchni służącej ekspozycji reklamy, w szczególności baner reklamowy, reklama naklejana na okna budynków i reklama umieszczana na rusztowaniu, ogrodzeniu lub wyposażeniu placu budowy, z wyłączeniem drobnych przedmiotów codziennego użytku wykorzystywanych zgodnie z ich przeznaczeniem. Nie określono zatem w sposób wyczerpujący różnych rodzajów tablic reklamowych. Wskazano jedynie na najbardziej typowe i stosowane najpowszechniej rodzaje tablic reklamowych, o czym przesądza użyty w treści wyżej cytowanego przepisu zwrot „w szczególności”.

Sposób zdefiniowania tablic reklamowych może stanowić zatem źródło różnych wątpliwości interpretacyjnych, w tym także o charakterze fundamentalnym, tzn. dotyczących zakwalifikowania określonych przedmiotów materialnych do pojęciowej kategorii „tablica reklamowa” lub ewentualnego wykluczenia z tej kategorii. Pozostawienie przez ustawodawcę katalogu otwartego rodzajów tablic reklamowych może mieć również negatywny wpływ na poprawną interpretację pojęcia „urządzenie reklamowe”. Według art. 2 pkt 16c u.p.g.p. jest nim przedmiot materialny przeznaczony lub służący ekspozycji reklamy wraz z jego elementami konstrukcyjnymi i zamocowaniami, inny niż tablica reklamowa, z wyłączeniem drobnych przedmiotów codziennego użytku wykorzystywanych zgodnie z ich przeznaczeniem. Jeżeli nie zdefiniowano w sposób jednoznaczny pojęcia „tablica reklamowa” i jednocześnie w definicji „urządzenia reklamowego" odniesiono się do tego pojęcia wskazując, że jest nim „przedmiot (...) inny niż tablica reklamowa”, to tym samym stworzono warunki do podejmowania różnych działań interpretacyjnych zmierzających do zakwalifikowania określonych przedmiotów materialnych służących do ekspozycji reklamy do kategorii „urządzenie reklamowe” lub zmierzających do wykluczenia ich z tej kategorii.

Zdefiniowanie w ten sposób w ustawie ww. pojęć należy ocenić krytycznie, w tym również z punktu widzenia standardów określających wy- 
znaczanie przedmiotowych granic opłaty reklamowej (wymierzanej od umieszczonych tablic reklamowych lub urządzeń reklamowych) oraz podstaw nakładania kar pieniężnych za umieszczanie tablic reklamowych lub urządzeń reklamowych niezgodnie z przepisami odpowiedniej uchwały rady gminy. Jeżeli w określonych sytuacjach nie będzie możliwe jednoznaczne ustalenie, czy dany przedmiot materialny jest lub nie jest tablicą reklamową albo urządzeniem reklamowym, to ewentualne nałożenie obowiązku zapłaty opłaty reklamowej lub ww. kary pieniężnej nie znajdzie uzasadnienia w obowiązującym porządku prawnym. W sytuacji, gdy tekst ustawy daninowej co do nałożonego obowiązku jest niejasny, jego interpretator ma obowiązek wyboru tego z kilku możliwych znaczeń, które zapewnia najdalej idącą ochronę podmiotu zobowiązanego, nawet kosztem państwa ${ }^{13}$.

Przedmiot ciężarów i świadczeń publicznych, w tym podatków i innych danin publicznych, powinien być - zgodnie z art. 84 i art. 217 Konstytucji $\mathrm{RP}^{14}$ - określony w ustawie. Charakter innych danin publicznych mają bez wątpienia opłaty reklamowe oraz omawiane w opracowaniu kary pieniężne. Głoszony jest pogląd, że na potrzeby wykładni norm i zasad konstytucyjnych należy przyjmować szersze rozumienie takich pojęć jak podatki czy daniny publiczne niż używane na gruncie prawa podatkowego $^{15}$. W cytowanych wyżej przepisach Konstytucji RP nie wymieniono wprost opłat, ale powinny one być kwalifikowane do kategorii „inne daniny publiczne”, o ile mają przymusowy charakter, a wpływy z ich tytułu są przeznaczane na cele publiczne. Niemniej jednak nie można bez zastrzeżeń zaakceptować sytuacji, w której w celu zapewnienia szczelności systemu danin publicznych organy podatkowe w drodze wykładni prawa dokonują za ustawodawcę korekty unormowań podatkowych. Działania takie - zgodnie z art. 217 Konstytucji RP - należą do sfery wyłącznej kompetencji organów władzy ustawodawczej. Przepis

13 J. Niedojadło, Nullum tributum sine lege - dopuszczalność wyboru drogi najmniej opodatkowanej, „Studia Prawnicze i Administracyjne” 2014, nr 1, s. 54.

14 Konstytucja Rzeczypospolitej Polskiej z dnia 2 kwietnia 1997 r. (Dz.U. Nr 78, poz. 483 ze zm.).

15 A. Krzywoń, Podatki i inne daniny publiczne - podstawowe pojęcia konstytucyjne, „Zeszyty Naukowe Sądownictwa Administracyjnego” 2011, nr 2, s. 57. 
ten, interpretowany łącznie z art. 2 i art. 7 Konstytucji RP, stanowi w polskim systemie prawa daninowego fundament ochrony jednostki (czy szerzej podmiotów podległych władztwu podatkowemu) przed przejawami arbitralności władz podatkowych. To władza publiczna, a nie podległe jej podmioty, musi ponosić konsekwencje niedoskonałego ukształtowania regulacji daninowej ${ }^{16}$.

Przepis art. 217, obok art. 84 Konstytucji, jest jednym z dwóch najważniejszych przepisów w zakresie regulacji danin publicznoprawnych, stanowi podstawę funkcjonowania krajowego systemu daninowego. Wynika z niego, że obligatoryjne elementy konstrukcji prawnej daniny publicznej normuje każdorazowo ustawa. Przewiduje zatem bezwzględną wyłączność ustawową podstawowych elementów konstrukcyjnych danin publicznych. Ustawodawca w odniesieniu do tych elementów nie pozostawił swobody regulacyjnej organom władzy wykonawczej ${ }^{17}$. Warunek ten jest spełniony w odniesieniu do zarówno opłat reklamowych, jak i kar pieniężnych wymierzanych za nielegalne umieszczanie w przestrzeni publicznej tablic oraz urządzeń reklamowych.

Tablica reklamowa oraz urządzenie reklamowe zawierają się w szerszej kategorii pojęciowej, jaką jest szyld. Zgodnie z art. 2 pkt 16d u.p.g.p. szyldem jest tablica reklamowa lub urządzenie reklamowe informujące o działalności prowadzonej na nieruchomości, na której ta tablica reklamowa lub urządzenie reklamowe się znajdują. W piśmiennictwie oceniono, że szyld jest kwalifikowaną formą tablicy reklamowej oraz urządzenia reklamowego ${ }^{18}$.

Określoną tablicę lub urządzenie tylko wtedy można uznać za „reklamowe”, gdy będą one przeznaczone do ekspozycji reklamy. Zgodnie z art. 2 pkt 16a u.p.g.p. reklama polega na upowszechnianiu w jakiejkolwiek wizualnej formie informacji promującej osoby, przedsiębiorstwa, towary, usługi, przedsięwzięcia lub ruchy społeczne. W aktach prawa miejscowego dotyczących planowania i zagospodarowania przestrzenne-

\footnotetext{
Wyrok NSA z dnia 20 października 2016 r., II FSK 1582/16, Legalis nr 1534757. Wyrok NSA z dnia 19 marca 2015 r., I GSK 1987/13, Legalis nr 1217812.

M.J. Nowak, Ustawa krajobrazowa - potencjalne problemy prawne, „Nieruchomości” 2015, nr 12, s. 4.
} 
go nie jest dopuszczalne odmienne definiowanie pojęć „reklama”, „tablica reklamowa” oraz „urządzenie reklamowe”19.

W rozumieniu przepisów ustawy z dnia 7 lipca 1994 r. Prawo budowlane $^{20}$ wolno stojące trwale związane $\mathrm{z}$ gruntem tablice reklamowe i urządzenia reklamowe są budowlami, natomiast prace dotyczące bezpośrednio „trwałych” elementów obiektu budowlanego, np. trwałe instalowanie tablic reklamowych, to roboty budowlane ${ }^{21}$. Reklama jest trwale związana z gruntem, pomimo że fundament na którym została umieszczona nie jest położony nawet częściowo poniżej poziomu gruntu. Cecha trwałego związania z gruntem sprowadza się bowiem do posadowienia obiektu na tyle trwale, aby zapewnić mu stabilność i możliwość przeciwdziałania czynnikom zewnętrznym, mogącym go zniszczyć lub spowodować przesunięcie czy przemieszczenie na inne miejsce. O tym, czy urządzenie reklamowe jest trwale związane z gruntem, nie decyduje metoda i sposób związania z gruntem, ale to, czy wielkość konkretnego urządzenia, jego konstrukcja, przeznaczenie i względy bezpieczeństwa wymagają takiego trwałego związania z gruntem ${ }^{22}$. Wolno stojące urządzenie reklamowe związane trwale z gruntem w sensie fizycznym jest zatem budowlą i nie ma znaczenia, czy zostało ono wzniesione dla przemijającego użytku ${ }^{23}$.

\section{Określanie zasad i warunków sytuowania tablic i urządzeń reklamowych}

Na podstawie art. 37a u.p.g.p. rada gminy jest upoważniona do podjęcia uchwały określającej zasady i warunki sytuowania tablic reklamowych i urządzeń reklamowych (tzw. uchwała reklamowa). W tej uchwale rada

19 Rozstrzygnięcie nadzorcze Wojewody Wielkopolskiego z dnia 7 lutego 2017 r., KN-I.4131.1.106.2017.5, (Dz.Urz. Woj. Wielkopolskiego z 2017 r., poz. 1248).

20 Tekst jedn. Dz.U. z 2016 r., poz. 290 ze zm.

21 R. Szostak, Planowanie i szacowanie zamówień publicznych $w$ świetle zmienionej regulacji prawnej, „Zamówienia Publiczne Doradca” 2010, nr 11, s. 8.

22 Wyrok WSA w Gdańsku z dnia 16 lipca 2014 r., II SA/Gd 235/14, LEX nr 1500277; wyrok NSA z dnia 14 lutego 2014 r., II OSK 2219/12, LEX nr 1569031.

23 R. Dowgier, Glosa do wyroku NSA z dnia 20 stycznia 2012 r., II FSK 1405/10, „Przegląd Podatków Lokalnych i Finansów Samorządowych” 2013, nr 2, s. 38. 
gminy może ustalić zakaz sytuowania tablic reklamowych i urządzeń reklamowych, z wyłączeniem szyldów.

Uchwała reklamowa powinna być odrębnym aktem prawnym od uchwały w sprawie miejscowego planu zagospodarowania przestrzennego mającej odmienny zakres przedmiotowy wyznaczony przepisami art. 15 ust. 2-3 u.p.g.p. ${ }^{24}$. Żaden miejscowy plan zagospodarowania przestrzennego, w stosunku do którego uchwałę o przystąpieniu do jego sporządzania lub zmiany podjęto po dniu wejścia w życie ustawy o zmianie niektórych ustaw w związku ze wzmocnieniem narzędzi ochrony krajobrazu, nie może już zawierać ustaleń dotyczących zasad i warunków sytuowania tablic reklamowych i urządzeń reklamowych. W świetle aktualnie obowiązującego stanu prawnego brak jest możliwości podejmowania działań legislacyjnych polegających na dokonaniu przemieszania materii planu miejscowego i tzw. uchwały reklamowej, której zakres przedmiotowy określa art. 37a ust. 1 u.p.g.p. Zasady i warunki sytuowania tablic i urządzeń reklamowych mogą zostać ustanowione wyłącznie w oparciu o procedurę regulowaną w art. 37a-37e u.p.g.p. ${ }^{25}$.

W odniesieniu do szyldów w uchwale reklamowej określa się zasady i warunki ich sytuowania, gabaryty oraz liczbę szyldów, które mogą być umieszczone na danej nieruchomości przez podmiot prowadzący na niej działalność. Uchwała reklamowa dotyczy całego obszaru gminy, z wyłączeniem terenów zamkniętych ustalonych przez inne organy niż ministra właściwego do spraw transportu. W uchwale można jednak zamieścić różne regulacje dla różnych obszarów gminy, określając w sposób jednoznaczny granice tych obszarów. W takim przypadku uchwała reklamowa może zawierać załącznik graficzny wraz z opisem, jednoznacznie określającym ich granice. Uchwała powinna ustalać warunki i termin dostosowania istniejących w dniu jej wejścia w życie tablic reklamowych i urządzeń

24 Rozstrzygnięcie nadzorcze Wojewody Opolskiego z dnia 12 października 2016 r., IN.VI.743.57.2016.AD, (Dz.Urz. Woj. Opolskiego 2016 r., poz. 2110); rozstrzygnięcie nadzorcze Wojewody Zachodniopomorskiego z dnia 6 września 2016 r., P-1.4131.202.2016.K, (Dz.Urz. Woj. Zachodniopomorskiego 2016 r., poz. 3450).

25 Rozstrzygnięcie nadzorcze Wojewody Dolnośląskiego z dnia 31 marca 2017 r., NKN.4131.82.8.2017.MC, Legalis nr 1580648. 
reklamowych do zakazów, zasad i warunków w niej określonych, nie krótszy niż 12 miesięcy od dnia jej wejścia w życie.

Podjęcie uchwały reklamowej powinno być poprzedzone konsultacjami, ponieważ jej rozstrzygnięcia mogą wywierać istotny wpływ na prawa właścicieli nieruchomości. Pierwszym etapem jest podjęcie przez radę gminy uchwały o przygotowaniu przez organ wykonawczy gminy projektu uchwały reklamowej. Wójt (burmistrz, prezydent miasta) niezwłocznie podaje do publicznej wiadomości informację o podjęciu przez radę gminy tej uchwały oraz sporządza projekt uchwały w sprawie zasad i warunków sytuowania tablic reklamowych i urządzeń reklamowych, a następnie zasięga opinii regionalnego dyrektora ochrony środowiska, właściwego organu Państwowej Straży Pożarnej oraz marszałka województwa o tym projekcie uchwały. Ponadto zadaniem organu wykonawczego gminy jest uzgodnienie tego projektu z wojewódzkim konserwatorem zabytków (w zakresie kształtowania zabudowy i zagospodarowania terenu) oraz z ministrem właściwym do spraw zdrowia (w zakresie zagospodarowania obszarów ochrony uzdrowiskowej). Organ wykonawczy gminy powinien ogłosić w prasie lokalnej oraz obwieścić, a także w sposób zwyczajowo przyjęty na danym terenie wyłożyć projekt tej uchwały do publicznego wglądu na okres co najmniej 21 dni (w czasie wyłożenia

i przez okres 14 dni po zakończeniu okresu wyłożenia zbierane są uwagi do tego projektu). Rada gminy, uchwalając uchwałę, rozstrzyga jednocześnie o sposobie rozpatrzenia uwag nieuwzględnionych przez wójta (burmistrza, prezydenta miasta).

Procedura konsultacji, których przedmiotem jest projekt ww. uchwały, obejmuje zatem formułowanie opinii, które nie mają charakteru wiążącego dla organu wykonawczego gminy, a także uzgadnianie projektu uchwały z właściwymi organami oraz zbieranie uwag do projektu w trakcie jego publicznego wyłożenia ${ }^{26}$. Niewyrażenie opinii w terminie miesiąca od dnia otrzymania projektu uchwały przez organy wymienione

26 Szerzej na temat znaczenia zwrotów „zasięganie opinii” i „uzgadnianie projektu” zob. np. M. Ofiarska, Formy publicznoprawne współdziałania jednostek samorzq̨du terytorialnego, C.H. Beck Warszawa 2008, s. 67-70. 
w ustawie oznacza, że obowiązek zasięgnięcia opinii został spełniony. Brak zajęcia stanowiska w terminie miesiąca od dnia otrzymania projektu uchwały przez właściwy organ oznacza, że nastąpiło uzgodnienie tego projektu w przedłożonym brzmieniu. Organ wykonawczy gminy niezwłocznie rozpatruje zgłoszone uwagi przez uprawnione podmioty i sporządza listę nieuwzględnionych uwag. Podjęta przez radę gminy uchwała określająca zasady i warunki sytuowania tablic reklamowych i urządzeń reklamowych jest aktem prawa miejscowego, podlega ogłoszeniu w wojewódzkim dzienniku urzędowym.

\section{Analiza wybranych postanowień uchwał podejmowanych w sprawach zasad i warunków sytuowania tablic reklamowych i urządzeń reklamowych}

Analizie poddano wyłącznie postanowienia uchwał rad gmin podjętych w 2016 r. i w pierwszym półroczu 2017 r. Wybór ten jest uzasadniony tym, że nowe uregulowania ustawowe dotyczące porządkowania krajobrazu weszły w życie 11 września 2015 r. Względnie długa procedura konsultowania projektów uchwał w sprawach zasad i warunków sytuowania tablic reklamowych i urządzeń reklamowych, a następnie podejmowania tych uchwał przez rady gmin sprawiła, że dostosowane do nowych uwarunkowań ustawowych są uchwały podejmowane od 2016 r.

Uchwały reklamowe powinny być podejmowane na podstawie upoważnienia 37a u.p.g.p. Jednak pomimo obowiązywania odrębnej procedury podejmowania ww. uchwał, regulowanej przepisami art. 37a-37e u.p.g.p., można wskazać jeszcze liczne przykłady regulowania zasad i warunków sytuowania tablic oraz urządzeń reklamowych w uchwałach w sprawach miejscowych planów zagospodarowania przyjmowanych na podstawie art. 18 ust. 2 pkt 5 ustawy z dnia 8 marca 1990 r. o samorządzie 
gminnym $^{27}$ oraz art. 20 ust. 1 u.p.g.p. Podejmowanie odrębnych „uchwał reklamowych” na podstawie art. 37a u.p.g.p. jest dotychczas wyjątkiem ${ }^{28}$.

Standardowe postanowienia dotyczą przede wszystkim zakazu umieszczania urządzeń reklamowych na terenach zieleni otwartej oraz na terenach dróg, natomiast dopuszczają lokalizację takich urządzeń na pozostałych terenach ${ }^{29}$. Formułowane są także lokalizacje urządzeń reklamowych na obszarach funkcjonalnych śródmieścia z zabudową mieszkaniową wielorodzinną, ale jednocześnie wprowadza się wyjątek dla takich urządzeń umieszczanych na elewacjach budynków usługowych, z zachowaniem określonych warunków (np. powierzchnia pojedynczego urządzenia nie może przekraczać $8 \mathrm{~m}^{2}$ i 5\% powierzchni elewacji ani przesłaniać otworów okiennych, drzwiowych oraz detali architektonicznych). Celem tych zakazów lub ograniczeń jest ochrona i właściwe kształtowanie ładu przestrzennego ${ }^{30}$. Realizując identyczny cel, zakazano lokalizacji jakichkolwiek urządzeń reklamowych wzdłuż drogi powiatowej oraz jednocześnie wprowadzono wyjątek dla szyldów wolnostojących o odpowiedniej wysokości (np. do $3 \mathrm{~m}$ ) i o określonej maksymalnej łącznej powierzchni na jednej działce (np. nieprzekraczającej $4 \mathrm{~m}^{2}$ ) lub umieszczanych na elewacji budynku lub na ogrodzeniu o maksymalnej łącznej powierzchni na jednej działce (np. nieprzekraczającej $\left.4 \mathrm{~m}^{2}\right)^{31}$.

Ograniczenia w sytuowaniu urządzeń reklamowych polegają także na ustalaniu dopuszczalnej wysokości wolnostojących urządzeń grupujących szyldy (np. do 2,5 m) oraz wolnostojących tablic i urządzeń reklamowych

Tekst jedn. Dz.U. z 2017 r., poz. 1875.

28 Np. uchwała Rady Miasta Opola z dnia 29 grudnia 2016 r. w sprawie ustalenia zasad i warunków sytuowania obiektów małej architektury, tablic reklamowych i urządzeń reklamowych oraz ogrodzeń w Opolu (Dz.Urz. Woj. Opolskiego z 2017 r., poz. 129).

29 Np. uchwała Rady Miasta Poznania z dnia 25 kwietnia 2017 r. w sprawie miejscowego planu zagospodarowania przestrzennego „Strefa przemysłowa przy ulicy Bałtyckiej” w Poznaniu (Dz.Urz. Woj. Wielkopolskiego z 2017 r., poz. 3728).

30 Np. uchwała Rady Miasta Poznania z dnia 24 stycznia 2017 r. w sprawie miejscowego planu zagospodarowania przestrzennego „W rejonie ulicy Dolna Wilda” w Poznaniu (Dz.Urz. Woj. Wielkopolskiego z 2017 r., poz. 1184).

31 Np. uchwała Rady Gminy Dopiewo z dnia 24 kwietnia 2017 r. w sprawie miejscowego planu zagospodarowania przestrzennego w obrębie geodezyjnym Trzcielin terenu wzdłuż drogi powiatowej Dopiewo - Stęszew (Dz.Urz. Woj. Wielkopolskiego z 2017 r., poz. 3776). 
niebędących szyldami (np. do $5 \mathrm{~m}$ ), a także ustalaniu łącznej powierzchni tablic i urządzeń reklamowych na jednej nieruchomości (np. nie więcej niż $0,05 \%$ powierzchni nieruchomości) ${ }^{32}$. Stosowane są także rozwiązania polegające na wskazaniu konkretnych lokalizacji urządzeń reklamowych wraz z innymi urządzeniami, np. infrastruktury technicznej, małej architektury lub służących utrzymaniu porządku (kosze na śmieci, trzepaki, ogrodzenia i osłony) ${ }^{33}$. Ograniczenia w lokalizacji tablic reklamowych lub urządzeń reklamowych mogą być wewnętrznie złożone, np. poprzez wskazanie rodzajów obszarów (terenów produkcyjnych i usług, terenów logistyki, składów, magazynów oraz usług związanych z obsługą komunikacyjną i pasażerską w transporcie drogowym) i rodzajów urządzeń reklamowych (np. tylko tablic reklamowych o powierzchni mierzonej w obrysie zewnętrznym do $6 \mathrm{~m}^{2}$ oraz słupów ogłoszeniowych) ${ }^{34}$. Ograniczenia polegają także na umożliwieniu lokalizacji tylko jednego elementu reklamowego przedsiębiorcy $\mathrm{w}$ formie szyldu, tablicy reklamowej lub kasetonu, z jednoczesnym określeniem dopuszczalnej (ściśle limitowanej) powierzchni reklamowej, materiału, z którego może być ten element wykonany (kamień naturalny, blacha miedziana lub mosiężna, blacha czarna oksydowana matowo, z zastosowaniem liter klasycznych lub stylizowanych), a także lokalizacji elementu reklamowego (np. na elewacjach parterów budynków lub prostopadle do ściany parteru budynku na wysokości powyżej 2,5 m nad chodnikiem oraz nie wyżej niż parter lub dolna krawędź pasa oddzielającego parter od piętra bądź dolna krawędź gzymsu okapowego budynku parterowego $)^{35}$.

32 Np. uchwała Rady Miejskiej w Łomiankach z dnia 13 października 2016 r. w sprawie miejscowego planu zagospodarowania przestrzennego „Łomianki Prochownia” (Dz.Urz. Woj. Mazowieckiego 2016 r., poz. 10689).

33 Np. uchwała Rady Miejskiej w Suwałkach z dnia 27 kwietnia 2016 r. w sprawie miejscowego planu zagospodarowania przestrzennego terenu położonego pomiędzy ulicą Reja a ulicą Szpitalną w Suwałkach (Dz.Urz. Woj. Podlaskiego z 2016 r., poz. 2226). Np. uchwała Rady Gminy Żabia Wola z dnia 25 października 2016 r. w sprawie miejscowego planu zagospodarowania przestrzennego Gminy Żabia Wola obejmującego fragment miejscowości Słubica (Dz.Urz. Woj. Mazowieckiego z 2017 r., poz. 299).

35 Np. uchwała Rady Miejskiej w Końskich z dnia 27 października 2016 r. w sprawie uchwalenia miejscowego planu zagospodarowania przestrzennego obejmującego fragment terenu miasta Końskie w granicach ulic: Marszałka Piłsudskiego, Iwo Odrowąża, Spółdzielczej i Targowej (Dz.Urz. Woj. Świętokrzyskiego z 2016 r., poz. 3882). 
Generalnie zakazuje się również lokalizowania wielkogabarytowych urządzeń reklamowych (tzn. przekraczających określoną powierzchnię lub wysokość), ale z wyjątkami dotyczącymi ich lokalizowania na czas odbywających się wystaw, pokazów i imprez oraz w celu wykonywania obowiązków związanych z informacją publiczną ${ }^{36}$.

Formułowane są również zakazy lokalizowania tablic reklamowych, które nie mają jednoznacznego charakteru i mogą być różnie interpretowane, np. wprowadzono zakaz umieszczania tablic reklamowych i szyldów w sąsiedztwie określonej drogi krajowej skierowanych do użytkowników tej drogi lub mogących rozpraszać ich uwagę ${ }^{37}$. Nie sprecyzowano jednak, jakie tablice reklamowe oraz szyldy mogłyby rozpraszać uwagę użytkowników dróg, np. ze względu na ich określoną treść, dobór kolorów lub wielkość powierzchni reklamowej. Określona tablica reklamowa lub szyld mogą w różny sposób oddziaływać na różnych użytkowników dróg lub mogą pozostawać neutralne w odniesieniu do ich zmysłów. Mniej wątpliwości interpretacyjnych pojawia się w przypadku ograniczeń polegających na możliwości sytuowania wolnostojących urządzeń reklamowych zawierających informacje związane $\mathrm{z}$ funkcją danego terenu ${ }^{38}$.

Konkludując, standardowe ograniczenia odnoszące się do warunków lokalizowania tablic reklamowych lub urządzeń reklamowych w przestrzeni publicznej polegają przede wszystkim na ustalaniu dopuszczalnej ich powierzchni lub dopuszczalnej wysokości. Inny typ ograniczeń polega na formułowaniu bezwzględnego zakazu umieszczania takich tablic lub urządzeń w określonych miejscach oraz jednoczesnym wskazaniu innych miejsc, w których dopuszcza się lokalizację tablic lub urządzeń reklamo-

36 Np. uchwała Rady Miasta Krakowa z dnia 15 marca 2017 r. w sprawie uchwalenia miejscowego planu zagospodarowania przestrzennego obszaru „Lema - Park Lotników Polskich” (Dz.Urz. Woj. Małopolskiego z 2017 r., poz. 2104).

Np. uchwała Rady Miejskiej w Tuliszkowie z dnia 24 lutego 2017 r. w sprawie uchwalenia miejscowego planu zagospodarowania przestrzennego Zadworna IV (Dz.Urz. Woj. Wielkopolskiego z 2017 r., poz. 2096).

38 Np. uchwała Rady Miejskiej w Łodzi z dnia 10 lutego 2016 r. w sprawie uchwalenia miejscowego planu zagospodarowania przestrzennego dla części obszaru miasta Łodzi obejmującej park pn. „Źródła Olechówki”, położonej w rejonie alei Ofiar Terroryzmu 11 Września oraz ulic: Kazimierza Odnowiciela, Transmisyjnej i Bolka Świdnickiego (Dz.Urz. Woj. Łódzkiego z 2016 r., poz. 917). 
wych (głównie na elewacjach budynków), ale z zastosowaniem limitu powierzchni przeznaczonej na ekspozycję reklamy. Stosowane są niekiedy rozwiązania polegające na precyzyjnym określaniu miejsc lokalizacji tablic i urządzeń reklamowych wraz z wyliczeniem materiałów, z których mogą one być wykonane.

W tzw. uchwałach reklamowych zamieszczane są natomiast bardzo precyzyjne postanowienia w postaci zakazów lokalizowania tablic i urządzeń reklamowych, np.: na pomnikach przyrody, na drzewach i w zasięgu ich koron oraz w sposób pogarszający warunki wegetacji roślin, na terenach zieleni, a także w granicach zbiorników wodnych i wód płynących; na drogowych obiektach inżynierskich, budowlach o funkcji dźwiękochłonnej. Ograniczenia mogą natomiast polegać na obowiązku dostosowania tablic reklamowych i urządzeń reklamowych pod względem kolorystyki, stylu, formy, kroju pisma i materiału do kompozycji architektonicznej i charakteru budynku lub budowli, na których się znajdują ${ }^{39}$.

\section{Status prawny i konstrukcja oraz metody ustalania wysokości kary pieniężnej za nielegalne umieszczanie tablic i urządzeń reklamowych}

$\mathrm{W}$ art. 37d u.p.g.p. ustalono podmiotowe, przedmiotowe oraz kwotowe granice kar pieniężnych za nielegalne umieszczanie tablic lub urządzeń reklamowych, a także określono przeznaczenie wpływów osiąganych z tych kar. Możliwe są dwa alternatywne rozwiązania dotyczące ustalenia podmiotu zobowiązanego do zapłaty omawianej kary pieniężnej, ale nie oznacza to możliwości dokonania swobodnego wyboru tego podmiotu przez organ wymierzający karę pieniężną. Zasadą jest wymierzenie kary pieniężnej podmiotowi, który umieścił tablicę reklamową lub urządzenie reklamowe niezgodne z przepisami uchwały podjętej przez radę gminy ustalającej zasady i warunki lokalizowania tablic i urządzeń reklamowych. Jeżeli jednak nie jest możliwe ustalenie takiego podmiotu, to karę

39 Np. cytowana już wyżej uchwała Rady Miasta Opola z dnia 29 grudnia 2016 r. 
pieniężną wymierza się odpowiednio właścicielowi, użytkownikowi wieczystemu lub posiadaczowi samoistnemu nieruchomości lub obiektu budowlanego, na których umieszczono tablicę reklamową lub urządzenie reklamowe.

W tym drugim przypadku dochodzi zatem do szczególnego rodzaju kumulacji zobowiązań pieniężnych, bowiem taki podmiot jest zobowiązanym w zakresie opłaty reklamowej pobieranej z tytułu tablic lub urządzeń reklamowych znajdujących się na tych nieruchomościach lub obiektach budowlanych, niezależnie od tego, czy są na nich eksponowane reklamy, a także jest podatnikiem podatku od nieruchomości. Kara pieniężna jest sankcją finansową za nielegalne umieszczenie tablicy reklamowej lub urządzenia reklamowego i w odróżnieniu od opłaty reklamowej nie można kwoty zapłaconego podatku od nieruchomości od tablicy reklamowej lub urządzenia reklamowego zaliczyć na poczet tej kary pieniężnej ${ }^{40}$.

Organem wymierzającym karę pieniężną, w drodze decyzji, jest wójt (burmistrz, prezydent miasta). W przypadku naruszenia zasad i warunków sytuowania tablic lub urządzeń reklamowych, określonych w uchwale rady gminy, organ wykonawczy gminy nie może odstąpić od wymierzenia kary pieniężnej. Przesądzają o tym użyte w treści art. 37d u.p.g.p. następujące zwroty: „podlega karze pieniężnej”, „karę pieniężną wymierza się” oraz „wysokość kary pieniężnej ustala się”. W żadnym przypadku ustawodawca nie użył zwrotu „może wymierzyć” lub „może ustalić”. Naruszenie zatem określonego zakazu lub innego ograniczenia zamieszczonego w uchwale rady gminy określającej zasady i warunki sytuowania tablic lub urządzeń reklamowych jest pozytywną przesłanką wymierzenia kary pieniężnej.

Karę pieniężną wymierza się od dnia, w którym organ wszczął postępowanie w sprawie, do dnia dostosowania tablicy reklamowej lub urządzenia reklamowego do przepisów ww. uchwały rady gminy albo do dnia usunięcia tablicy lub urządzenia. Jeżeli w dniu wydania decyzji ustalającej wysokość kary pieniężnej tablica reklamowa lub urządzenie re-

40 Zgodnie z art. 17a u.p.o.l. kwotę zapłaconego podatku od nieruchomości od tablicy reklamowej lub urządzenia reklamowego zalicza się na poczet opłaty reklamowej należnej od tej tablicy reklamowej lub urządzenia reklamowego. 
klamowe nie są zgodne z przepisami uchwały rady gminy, to w decyzji tej określa się:

a) wysokość kary pieniężnej za okres od dnia wszczęcia postępowania w sprawie do dnia wydania decyzji, oraz

b) obowiązek dostosowania tablicy reklamowej lub urządzenia reklamowego do przepisów uchwały rady gminy albo usunięcia tablicy lub urządzenia (w zakresie tego obowiązku decyzja podlega natychmiastowemu wykonaniu, a po wykonaniu tego obowiązku organ określa, w drodze decyzji, wysokość kary pieniężnej za okres od dnia wydania decyzji odpowiednio do dnia dostosowania tablicy reklamowej lub urządzenia reklamowego do przepisów uchwały rady gminy albo usunięcia tablicy lub urządzenia).

W procedurze zmierzającej do dostosowania zlokalizowanych w przestrzeni publicznej tablic lub urządzeń reklamowych wydawane są dwie decyzje. W pierwszej decyzji określa się wysokość kary pieniężnej (od dnia wszczęcia postępowania do dnia wydania przedmiotowej decyzji) oraz nakłada obowiązek dostosowania tablicy lub urządzenia reklamowego do wymogów uchwały rady gminy lub obowiązek ich usunięcia. W związku z tym, że organ wykonawczy gminy wymierza karę pieniężną za cały okres, w którym występowała niezgodność z uchwałą określającą zasady i warunki sytuowania tablic i urządzeń reklamowych, jego obowiązkiem jest wydanie drugiej decyzji administracyjnej, w której ustala się karę pieniężną za okres od dnia wydania pierwszej decyzji do dnia dostosowania tablicy lub urządzenia reklamowego do wymogów ww. uchwały lub do dnia ich usunięcia ${ }^{41}$.

Ustawodawca dopuszcza dwie alternatywne metody ustalania wysokości kary pieniężnej. Pierwsza metoda jest stosowana wtedy, gdy w danej gminie rada gminy określiła wysokość stawek opłaty reklamowej ${ }^{42}$, które nie mogą być wyższe od stawek przyjętych w ustawie (tzw. stawek

41 Z. Niewiadomski, Komentarz do art. 37d, [w:] Z. Niewiadomski, K. Jaroszyński, A. Szmytt, Ł. Złakowski (red.), Planowanie i zagospodarowanie przestrzenne. Komentarz, Warszawa 2016, s. 318.

42 Zgodnie z art. 17a u.p.o.l. opłata reklamowa jest daniną publiczną o charakterze fakultatywnym, a o jej ewentualnym wprowadzeniu na obszarze danej gminy rozstrzyga rada gminy w drodze uchwały. 
maksymalnych). W takim przypadku wysokość kary pieniężnej ustala się jako iloczyn pola powierzchni tablicy reklamowej lub urządzenia reklamowego służącej ekspozycji reklamy, wyrażonej w metrach kwadratowych oraz 40-krotności uchwalonej przez radę gminy stawki części zmiennej opłaty reklamowej, powiększony o 40-krotność uchwalonej przez radę gminy stawki części stałej tej opłaty ${ }^{43}$, za każdy dzień niezgodności tablicy reklamowej lub urządzenia reklamowego z przepisami uchwały rady gminy.

Druga metoda ustalania wysokości kary pieniężnej jest stosowana wtedy, gdy rada gminy nie określiła wysokości stawek opłaty reklamowej. Wysokość kary pieniężnej ustala się jako iloczyn pola powierzchni tablicy reklamowej lub urządzenia reklamowego służącej ekspozycji reklamy, wyrażonej w metrach kwadratowych oraz 40-krotności maksymalnej stawki części zmiennej opłaty reklamowej, powiększony o 40-krotność maksymalnej stawki części stałej opłaty reklamowej, za każdy dzień niezgodności tablicy reklamowej lub urządzenia reklamowego z przepisami uchwały rady gminy.

Rada gminy nie ma zatem uprawnień do bezpośredniego kształtowania wysokości kar pieniężnych za umieszczanie w przestrzeni publicznej tablic lub urządzeń reklamowych niezgodnie z przepisami aktu prawa miejscowego określającymi zasady i warunki ich sytuowania. Może natomiast wywierać taki wpływ pośrednio, tzn. wprowadzając na obszarze gminy opłatę reklamową i określając wysokość stawek tej opłaty na poziomie niższym od stawek maksymalnych ustalonych przez ustawodawcę.

Wpływy z omawianych kar pieniężnych stanowią źródło dochodów gminy. W doktrynie wpływy z tego źródła są zaliczane do ogólnie określanej kategorii „inne dochody”44. Jest to źródło dochodów własnych gminy, o czym przesądzają postanowienia art. 4 ust. 1 pkt 6 ustawy z dnia 13 listopada 2003 r. o dochodach jednostek samorządu terytorialnego ${ }^{45}$.

43 W 2017 r. stawka części stałej opłaty reklamowej nie może przekroczyć 2,45 zł dziennie, natomiast dzienna stawka części zmiennej opłaty reklamowej nie może przekroczyć $0,20 \mathrm{zł}$ od $1 \mathrm{~m}^{2}$ pola powierzchni tablicy reklamowej lub urządzenia reklamowego służących ekspozycji reklamy.

44 E. Chojna-Duch, Prawo finansowe. Finanse publiczne, Warszawa 2017, s. 333.

45 Tekst jedn. Dz.U. z 2016 r., poz. 198 ze zm. 
Zgodnie z tym przepisem źródłami dochodów własnych gminy są dochody z kar pieniężnych określonych w odrębnych przepisach. W tym przypadku „odrębnymi przepisami” są przepisy art. 37d u.p.g.p.

Stosownie do postanowień art. 37e u.p.g.p. w sprawach nieuregulowanych w tej ustawie, a dotyczących omawianych kar pieniężnych stosuje się odpowiednio przepisy działu III (pt. Zobowiązania podatkowe) ustawy z dnia 29 sierpnia 1997 r. - Ordynacja podatkowa ${ }^{46}$, z tym że uprawnienia organów podatkowych przysługują wójtowi (burmistrzowi, prezydentowi miasta). W związku z tym organ wykonawczy gminy może m.in. stosować ulgi w zapłacie tych kar w postaci odraczania terminu zapłaty, rozkładania płatności na raty oraz częściowego lub całkowitego umorzenia zaległości z tytułu niezapłaconej w terminie kary pieniężnej. Określając przedmiotowy zakres stosowania przepisów ustawy Ordynacja podatkowa, w jej art. 2 wprost nie wymieniono kar pieniężnych. Można jednak przyjąć, że mieszczą się one w ogólniejszej kategorii pojęciowej stosowanej w przepisach tej ustawy, a mianowicie „niepodatkowych należnościach budżetu” państwa lub jednostki samorządu terytorialnego. Według art. 3 pkt 8 Ordynacji podatkowej niepodatkowe należności budżetowe to niebędące podatkami i opłatami należności stanowiące dochód budżetu państwa lub budżetu jednostki samorządu terytorialnego, wynikające ze stosunków publicznoprawnych. Oznacza to, że niepodatkowe należności budżetowe zostały przeciwstawione podatkom oraz opłatom, a więc są odrębnym od nich świadczeniem ${ }^{47}$. Na taki status prawny niektórych kar pieniężnych wskazują sądy administracyjne ${ }^{48}$. Kara pieniężna za nielegalne umieszczanie w przestrzeni publicznej tablic i urządzeń reklamowych jest rodzajem administracyjnej kary pieniężnej, ponieważ jest ona wymierzana nie przez sąd, lecz przez organ administracji publicznej w drodze

46 Tekst jedn. Dz.U. z 2017 r., poz. 201 ze zm.

47 A. Huchla, Niepodatkowe należności budżetowe w ustawie o finansach publicznych $i$ w ordynacji podatkowej, [w:] W. Miemiec, K. Sawicka (red.), Instytucje prawnofinansowe w warunkach kryzysu gospodarczego, Warszawa 2014, s. 258.

48 Np. wyrok NSA z dnia 18 października 2011 r., II GSK 1020/10, LEX nr 1070190; uchwała NSA z dnia 16 listopada 2009 r., I FPS 2/09, Orzecznictwo Sądów Polskich 2010, z. 5, poz. 54; wyrok WSA w Szczecinie z dnia 24 kwietnia 2014 r., II SA/Sz 1356/13, Legalis nr 980092. 
decyzji administracyjnej. Weryfikacja takiej decyzji następuje w trybie postępowania administracyjnego i podlega kontroli sądów administracyjnych. Ponadto kary pieniężne wymierzane przez organy administracji publicznej podlegają egzekucji administracyjnej. Administracyjne kary pieniężne są przez niektórych przedstawicieli doktryny zaliczane do kategorii „niepodatkowe należności budżetowe”49. W literaturze przedmiotu można jednak wskazać odmienne poglądy, według których do tej kategorii należy zaliczać tylko należności, których obowiązek ponoszenia stanowi realizację przepisów prawa i nie jest efektem naruszenia tych przepisów. Z tego względu do kategorii „niepodatkowe należności budżetowe” przedstawiciele tego nurtu nie zaliczają kar pieniężnych ${ }^{50}$.

\section{Uwagi końcowe}

Kary pieniężne za niezgodne z prawem umieszczanie w przestrzeni publicznej tablic reklamowych oraz urządzeń reklamowych, obok opłat reklamowych, mogą stać się ważnym instrumentem kształtowania krajobrazu w wymiarze lokalnym. Z analizy obowiązującego ustawodawstwa wynika, że wyżej wymienione instrumenty mogą być stosowane i równolegle, i odrębnie. Możliwe jest bowiem nakładanie takich kar pieniężnych zarówno wtedy, gdy na terenie gminy została wprowadzona opłata reklamowa i określono jej stawki, jak i wtedy, gdy na terenie gminy nie zdecydowano się na wprowadzenie opłaty reklamowej. Niezbędną podstawą prawną nakładania omawianych kar pieniężnych, w każdej z wyżej wskazanych sytuacji, jest uprzednie podjęcie przez radę gminy uchwały określającej zasady i warunki sytuowania tablic reklamowych i urządzeń reklamowych. Naruszenie bowiem tych zasad i warunków jest pozytywną przesłanką nałożenia kary pieniężnej.

49 Np. A. Drwiłło, Inne formy danin niepodatkowych [w:] L. Etel (red.), System prawa finansowego, t. 3, Prawo daninowe, Warszawa 2010, s. 924; M. Ślifirczyk, Niepodatkowe należności budżetowe, „Gdańskie Studia Prawnicze” 2007, nr 16, s. 347.

50 Np. M. Popławski, Komentarz do art. 3 [w:] L. Etel (red.), Ordynacja podatkowa. Komentarz, Warszawa 2017, s. 72; A. Borodo, Glosa do postanowienia NSA z dnia 9 września 2008 r., II GW 4/08, Orzecznictwo Sądów Polskich 2009, z. 12, poz. 133. 
Wójt (burmistrz, prezydent miasta), jako organ uprawniony do nałożenia kary pieniężnej, obowiązany jest działać w ramach wyznaczonych postanowieniami art. 37d u.p.g.p. Oznacza to, że nie może odstąpić od wymierzenia tej kary w przypadku naruszenia przez określony podmiot zasad i warunków ustalonych w uchwale rady gminy dotyczącej sytuowania tablic i urządzeń reklamowych. Nie jest również uprawniony do różnicowania wysokości kar pieniężnych stosowanych w poszczególnych przypadkach i w odniesieniu do konkretnych podmiotów. Wysokość tych kar ustalana jest jako iloczyn pola powierzchni tablicy reklamowej lub urządzenia reklamowego służącej ekspozycji reklamy (wyrażonej w metrach kwadratowych) i wielokrotność stawek opłaty reklamowej określonych przez radę gminy w ramach przysługującego jej władztwa daninowego. Jeżeli jednak rada gminy zrezygnuje $\mathrm{z}$ wprowadzenia opłaty reklamowej na swoim terenie, to w mechanizmie ustalania wysokości kar pieniężnych uwzględnia się maksymalne stawki opłaty reklamowej przyjęte na dany rok w ustawie o podatkach i opłatach lokalnych. W każdym natomiast przypadku organ wykonawczy gminy jest uprawniony do stosowania ulg w zapłacie uprzednio wymierzonych kar pieniężnych w postaci odroczenia terminu zapłaty, rozłożenia płatności na raty, umorzenia (częściowego lub całkowitego) zaległej kary pieniężnej. Stosowanie tych ulg uwarunkowane jest zaistnieniem przesłanek określonych w przepisach ustawy Ordynacja podatkowa.

Dopuszczalne jest wymierzanie kar pieniężnych w różnej wysokości na obszarze tej samej gminy. Możliwe jest to w sytuacji, w której rada gminy, korzystając z przysługującego jej władztwa daninowego, na podstawie art. 19 pkt 4 u.p.o.l. określi różną wysokość stawek opłaty reklamowej z uwzględnieniem lokalizacji oraz wielkości lub rodzaju tablicy reklamowej i urządzenia reklamowego. W różnych zatem miejscach na obszarze gminy mogą obowiązywać stawki opłaty reklamowej w odmiennej wysokości. Stwierdzenie naruszenia w konkretnym miejscu zasad i warunków sytuowania tablic i urządzeń reklamowych powinno zatem skutkować wyliczeniem kary pieniężnej z uwzględnieniem stawek opłaty reklamowej obowiązującej dla takiego miejsca. 
Konkludując, kary pieniężne za niezgodne z prawem umieszczanie w przestrzeni publicznej tablic reklamowych oraz urządzeń reklamowych są związane z ustawowo wyznaczonym zakresem władztwa planistycznego samorządu gminnego obejmującego ustalanie zasad lokalizacji tablic i urządzeń reklamowych oraz władztwa daninowego odnoszącego się do wprowadzania daniny publicznej $\mathrm{w}$ postaci opłaty reklamowej, w tym określania wysokości stawek tej opłaty.

Kary pieniężne mają charakter publicznoprawny i mieszczą się w szerszej kategorii niepodatkowych należności budżetowych gminy. Pełnią jednocześnie funkcję administracyjnej sankcji finansowej nakładanej na określony podmiot za nieprzestrzeganie postanowień prawa publicznego $^{51}$. Wpływy z tego tytułu stanowią źródło dochodów własnych gminy, ale mają one charakter uboczny. Podstawową funkcją kar pieniężnych nie jest funkcja fiskalna, lecz represyjna ${ }^{52}$. W zakresie nieuregulowanym w ustawie o planowaniu i zagospodarowaniu przestrzennym stosowane są do kar pieniężnych przepisy o zobowiązaniach podatkowych zawarte w ustawie Ordynacja podatkowa. Przymusowe ściągnięcie kar pieniężnych następuje według zasad i w trybie, które uregulowano w ustawie z dnia 17 czerwca 1966 r. o postępowaniu egzekucyjnym w administracji ${ }^{53}$.

Władztwo gminy w odniesieniu do elementów prawnej konstrukcji omawianych kar pieniężnych zostało jednak istotnie ograniczone przez ustawodawcę, który jednoznacznie ustalił mechanizm ustalania wysokości kar, a także okresy, za które mogą one być wymierzane. Tylko w sytuacji, w której rada gminy nie podejmie uchwały określającej zasady i warunki sytuowania tablic reklamowych i urządzeń reklamowych, nie będzie pod-

51 M. Kowalski, Niepodatkowe należności budżetowe a prawo unijne, [w:] I. Mirek, T. Nowak (red.), Prawo finansowe po transformacji ustrojowej. Międzynarodowe i europejskie prawo podatkowe, Łódź 2013, s. 500.

52 M. Duda, Komentarz do art. 111, [w:] P. Smoleń (red.), Ustawa o finansach publicznych. Komentarz, Warszawa 2014, s. 683; P. Stanisławiszyn, Wstęp do rozważań nad sankcjami prawno-finansowymi, [w:] M. Stahl, R. Lewicka, M. Lewicki (red.), Sankcje administracyjne. Blaski i cienie, Warszawa 2011, s. 247.

53 Tekst jedn. Dz.U. z 2016 r., poz. 599 ze zm. 
staw do wymierzania kar pieniężnych, ponieważ jedyną podstawą prawną ich nakładania nie mogą być przepisy ustawowe.

Umiejętne korzystanie z instrumentów finansowych w postaci opłat reklamowych oraz kar pieniężnych za niezgodne z ustalonymi zasadami i warunkami sytuowanie tablic i urządzeń reklamowych powinny w dłuższym okresie wywierać pozytywny wpływ na sytuację i rozwój lokalny. Nadrzędnym celem powinna być ochrona krajobrazu, w tym zwłaszcza terenów, na których występują krajobrazy priorytetowe. Celem wtórnym powinna natomiast pozostawać wydajność fiskalna opłat reklamowych i kar pieniężnych. Właściwa ochrona krajobrazu sprzyja poprawie poziomu atrakcyjności określonych terenów jako miejsc zamieszkania lub wypoczynku. Wykorzystanie tych instrumentów powinno przede wszystkim służyć kształtowaniu krajobrazu zgodnie ze standardami określonymi w Europejskiej Konwencji Krajobrazowej ${ }^{54}$. Według tego aktu prawa międzynarodowego krajobraz pełni ważną rolę w publicznych zainteresowaniach dziedzinami kultury, ekologii i sprawami społecznymi oraz stanowi zasób sprzyjający działalności gospodarczej. Odpowiednio planowany, ochraniany i zarządzany może przyczyniać się do rozwoju cywilizacyjnego oraz wzrostu gospodarczego. Krajobraz przyczynia się do tworzenia kultur lokalnych i stanowi ważny element jakości życia ludzi zamieszkujących obszary miejskie i wiejskie.

\section{Bibliografia:}

Borodo A., Glosa do postanowienia NSA z dnia 9 września 2008 r., II GW 4/08, „Orzecznictwo Sądów Polskich 2009”, z. 12, poz. 133.

Chojna-Duch E., Prawo finansowe. Finanse publiczne, Oficyna Prawa Polskiego, Warszawa 2017.

Dowgier R., Glosa do wyroku NSA z dnia 20 stycznia 2012 r., II FSK 1405/10, „Przegląd Podatków Lokalnych i Finansów Samorządowych” 2013, nr 2, s. 37-41.

54 Europejska Konwencja Krajobrazowa sporządzona we Florencji dnia 20 października 2000 r. (Dz.U. z 2006 r. Nr 14, poz. 98). 
Drwiłło A., Inne formy danin niepodatkowych [w:] L. Etel (red.), System prawa finansowego, t. 3, Prawo daninowe, Wolters Kluwer, Warszawa 2010, s. 923-928.

Duda M., Komentarz do art. 111, [w:] P. Smoleń (red.), Ustawa o finansach publicznych. Komentarz, C.H. Beck, Warszawa 2014, s. 674-686.

Huchla A., Niepodatkowe należności budżetowe w ustawie o finansach publicznych i w ordynacji podatkowej, [w:] W. Miemiec, K. Sawicka (red.), Instytucje prawnofinansowe $w$ warunkach kryzysu gospodarczego, Wolters Kluwer, Warszawa 2014, s. 257-268.

Kowalski M., Niepodatkowe należności budżetowe a prawo unijne, [w:] I. Mirek, T. Nowak (red.), Prawo finansowe po transformacji ustrojowej. Międzynarodowe i europejskie prawo podatkowe, Wydawnictwo Uniwersytetu Łódzkiego, Łódź 2013, s. 499-509.

Kręcisz W., Kary i opłaty za zajęcie pasa drogowego na cele niezwiqzane z użytkowaniem dróg w orzecznictwie sq̨dów administracyjnych, „Zeszyty Naukowe Sądownictwa Administracyjnego” 2014, nr 2, s. 23-39.

Krzywoń A., Podatki i inne daniny publiczne - podstawowe pojęcia konstytucyjne, „Zeszyty Naukowe Sądownictwa Administracyjnego” 2011, nr 2, s. 47-58.

Niedojadło J., Nullum tributum sine lege - dopuszczalność wyboru drogi najmniej opodatkowanej, „Studia Prawnicze i Administracyjne” 2014, nr 1, s. 53-60.

Nowak M.J., Ustawa krajobrazowa - potencjalne problemy prawne, „Nieruchomości” 2015, nr 12, s. 4-7.

Niewiadomski Z., Jaroszyński K., Szmytt A., Złakowski Ł., Planowanie i zagospodarowanie przestrzenne. Komentarz, C.H. Beck, Warszawa 2016.

Ofiarska M., Formy publicznoprawne współdziałania jednostek samorzqdu terytorialnego, C.H. Beck, Warszawa 2008.

Popławski M., Komentarz do art. 3, [w:] L. Etel (red.), Ordynacja podatkowa. Komentarz, Wolters Kluwer, Warszawa 2017.

Sobieralski K., Charakter prawny kary za zajęcie pasa drogowego, „Nowe Zeszyty Samorządowe” 2015, nr 2, s. 19-20.

Stanisławiszyn P., Wstęp do rozważań nad sankcjami prawno-finansowymi, [w:] M. Stahl, R. Lewicka, M. Lewicki (red.), Sankcje administracyjne. Blaski i cienie, Wolters Kluwer, Warszawa 2011, s. 242-259.

Szostak R., Planowanie i szacowanie zamówień publicznych w świetle zmienionej regulacji prawnej, „Zamówienia Publiczne Doradca” 2010, nr 11, s. 6-18.

Ślifirczyk M., Niepodatkowe należności budżetowe, „Gdańskie Studia Prawnicze” 2007, nr 16, s. 335-348. 